\title{
Democracy and Prevention of Corruption in the European Legislation
}

\author{
Ada Guven \\ Law Department, Faculty of \\ Humanities, Beder University College
}

\section{Abstract}

This article discuses the concept of democracy, corruption and the relationship between. Democracy and corruption have been perceived to be in a close and complex relationship with each other. Scholars have argued that a solid link exist between them. When democracy weakens, we can almost certainly expect an increase in corruption due to the attrition of institutional checks and balances, independence of courts and frequent restriction of the space for civil society actions and political rights of citizens. The paper analyses the large impact corruption has on democracy, and the states sustained efforts to limit corruption can improve the strength of democracy by promoting just and competitive elections, ensuring better quality and delivery of public services and improving citizens' trust in political institutions and governments. The paper in the second part observes the legal norms approved by the European legislation concerning the fight against corruption, it seems possible to outline an emerging model of corruption prevention by concluding that the effort of European and national legislation to limit corruption should be a contribution to the consolidation of democratic regimes and efforts to improve the quality of governance.

Keywords: democracy, corruption, rule of law, development

\section{Introduction}

\section{The relationship of Democracy and Corruption}

There is a strong relationship of democracy with bribery phenomena, even though that democracy because of being transparent is declared to be the least corrupt form of states. From studies conducted year after year, there have been conclusions that show that there is many countries rated with a high level of democracy but at the same time with a high level of corruption. In contrast, there have been studies showing that non-democratic as well as autocratic countries have been successful in maintaining a low level of corruption. We must keep in mind that before we begin to analyse the relationship between democracy and corruption, we must clarify the 
definition of these two concepts. For this we must first clearly specify what the term democracy will mean in this study. One of the views that also studies democracy is the electoral one. In this respect modern political democracy is the system in which the elected and those who have decision-making in the public sphere should be responsible for their actions towards citizens (Philippe C. Schmitter, Terry Lynn Karl, 1991). This view is a minimalist conception of the fact that vertical electoral responsibility is the most important bearing part of democracy. According to other scholars, democracy is defined to be in a broader sense, the definition should exceed competition during the election campaign and should include the consolidation of the rule of law as well as the balance of state institutions and respect for human rights (Merkel, 2004).

One of the aspects that scholars remain in extracting the content of the term democracy is that of democratic participation. In order to achieve full democratic participation, there must be the rule of law, freedom and equality of all citizens, respect for institutions in order to have a full involvement of citizens in the democratic election process. We must not forget the fact that in order to have a highlevel democracy, the three powers that form the state must be independent and control and balance each other (Selen A. Ercan, Jean-Paul Gagnon , 2014).

The concept of "embedded democracy has been advocated by scholars like Merkel. He defined that embedded democracy consist of five cumulative elements, that are independent and transparent elections, political participation rights, civil rights of citizens as well as horizontal accountability and effective power to govern (Munck, 2016).

However, Merkel also recognizes the importance of the impact it has on democracy, external factors and conditions that can strengthen governance such as civil society and cooperation with international organizations. All these constituent elements of democracy are a starting point for the debate on the relationship between democracy and corruption (Morlino, 2004).

The fact that democracy is a system built on effective horizontal accountability it means that there must be a balance between the three constituent powers of the state, the legislative, the executive and the judiciary (David Collier, Steven Levitsky, 1997). All of these must mutually control each other. One of the most important factors for the realization of this mutual control is the assurance of independence of the judicial system and the rule of law (David Collier, Steven Levitsky, 1997). Because prosecutors are the only institutions that can control whether politicians or civil servants abuse power for their own personal interests and then the courts can provide penalties for these violations of the law. The higher the assurance of the independence of the judicial system, the higher will be the provision of impartial application of the law, which leads to the reduction of corruption. Still, people tend to analyse the chances for them to be caught by law enforcement bodies and in that case whether they are going to be indicted in a harsh way or not. According o the rational choice theory 
citizen tent to adhere to law enforcement if the punishment is to severe (Susan RoseAckerman, Bonnie J. Palifka, 2016).

The question before us is whether a high democratic form of government can lead to the extermination of corruption. Different conclusions have emerged from the research. One of them is that corruption is directly related to the socio-economic development of countries, so the higher the development, the lower the corruption (Pablo M. Pinto, Boliang Zhu, 2016)

On the other hand, we must keep in mind that even with a high-level democracy, corruption still finds a way to live. Studies that have been conducted in many countries have concluded that the link between the maturity of democracy and the level of corruption is not linear. In new democracies, corruption finds more room to live by undermining the executive, legislative and judicial powers. These are more fragile, so that laws are not very consolidated, and penalties are not too harsh (Hanna Back, Axel Hadenius, 2008).

Therefore, it is possible that corruption "infests" these weak points. When corruption extends, it undermines one or more of the democratic pillars and can significantly impair the overall democratic strength. Ultimately, a perverse and vicious circle that reinforces corruption is installed and further undermines democratic processes (Bo Rothstein, Aiysha Varraich, 2017)

\section{2- The International Dimension of Corruption}

Corruption has historically been a major problem for the functioning and stability of state regulations. In fact, the spread of episodes of corruption among politicians and public officials contributes to delegitimizing the political-administrative system, alters the democratic circuit of political representation, affects the correct exercise of public powers and promotes the waste of public resources. Moreover, the phenomenology of corruption has become increasingly more complex, given that the traditional subjects of criminal law, public subject corrupted and private-corrupting subject, very often overlap other subjects with the task of mediating illegal transactions (Teachout, 2018).

To explain the spread of corrupt practices, in the sociological and criminological literature two main theories have been elaborated. These theories differ in relation to the identification of the cause of the corruption phenomena in contemporary societies (Mongillo, 2012).

The first theory supports the fact that the corruption matrix is essentially economic, in the sense that the choices underlying the payment or the acceptance of bribes are the result of a rational calculation made by the subjects involved in the illegal transaction, who tend to compare the costs (which includes the probability of being discovered and the severity of the penalties provided for) and the benefits expected from the unlawful behaviour with the costs deriving from the available alternatives. 
A second theory believes that the cause of corruption is socio-cultural, since the presence of corrupt practices in socio-institutional systems depends on the degree of entrenchment of moral values in civil society and on the consolidation of the "spirit of the body" and the meaning of the State among public officials (Mongillo, 2012). These two theories have similarities between them, so, they are complementary to each other while having both influenced recent policies to combat corruption.

Over the past few decades, economical growth has also increased ability to detect the negative effects that arise from the proliferation of corrupt practices, which are suitable for affecting different aspects of civil coexistence and the national economy. This awareness was formed through the knowledge acquired not only in the context of scientific research on this area, but also based on a series of studies and specialist insights that have been promoted by public institutions and by non-governmental organizations (Robinson, 2007). The researchers, have focused their studies in particularly in quantifying the economic costs using econometric methodologies, and have measured the additional indirect effects that entails a systematic spread of corruption in national political systems (Mo, 2001).

Scholars have ascertained that during time another international dimension of the phenomenon of corruption emerged and this could be attributed to various factors. One of the main important factors concerns the impact of the globalization of the economy which, by increasing the opportunities for commercial exchange between States and increasing competition between companies, can encourage the attempt to enter the foreign markets through the use of a bribe to obtain advantages and facilities from public administrations (Šumah, 2018). A second factor can be recognized in the role of multinationals companies. which, even following the erosion of the regulatory power of the nation-states, are capable of perpetrating transnational offenses, including those of a corruption type, by dividing the path of crime into several national territories, with the involvement of the various components of the corporate structure, so as to hinder the identification of the responsibility of the parent company (Šumah, 2018).

The mobility of economic activity allows large corporations, in with a view to "law shopping", that is, to choose the most favourable legal system, to also minimize the criminal risk, avoiding incurring the penalties imposed by the most severe orders among those in competition (Wells, 2014).

Furthermore, it should not be overlooked that corrupt practices now also increasingly affect officials of international organizations, who have become the centre of the decision-making process and decide the expenditure that are more important than ever from an economic point of view (Wells, 2014).

Studies have shown that both domestic and international corruption, created by public officials operating in the context of international institutions, are considered, in all institutional settings, as one of the main obstacles to economic globalization and 
the modernization of state's political systems, since they produce competitive distortions and cause bad allocation of public resources.

It should come as no surprise, therefore, that the main bodies and international organizations, such as the Organization for Economic Cooperation and Development (OECD), have been dedicated to promoting economic development globally, or regionally such as the European Union (EU), and even multilateral development banks, such as the International Monetary Fund and the World Bank (The Financial Action Task Force (FATF) , 2020). These international organizations have included the fight against corruption among the priorities of their political agendas, with the aim of stimulating national authorities to improve internal legislation by revising tools to combat corruption practices. In many cases, the goal of these institutions, especially those in economic vocation, it is not so much to preserve the integrity and correct functioning of the public administration involved in corruption offenses, but rather to avoid the competitive distortions generated by corruption, safeguarding both the correctness of international transactions and the interests of the participants in the global competition (Dahl, 2008). Therefore, we understand the need of international organizations to make the repressive responses to the corruption of foreign public officials as homogeneous as possible, helping to level the playing field for companies operating on a transnational scale.

In order to direct the initiatives of the supranational institutions and guide the legislative reforms of States it has been promoted the development of criteria and mechanisms for measuring both the economic damage caused by corruption and the degree of spread of corruption phenomena in national systems, with the preparation, among other things, of real and their own international rankings of states, in relation to the level of corruption they present.

Indeed, the models for measuring corruption are not unique, but can use three different categories of data: a) data taken from judicial data; b) the data derived from the outcome of the application of certain methodologies aimed at recording the perception of the phenomenon by the interviewees; c) data that take into account the direct experience of the respondents (United Nations Office on Drugs and Crime (UNODC), 2018). The latter measurement method makes use of indices that detect the direct experience of the interviewees upon episodes of corruption, also captured in its latent dimension. In the international context, these different analysis criteria are reflected. the World Bank periodically approves the rating of control of corruption (RCC), which is based on the opinions expressed by businesses and citizens, while the European Commission with Eurobarometer uses a periodic survey with which also includes the percentage of citizens who received the request or offer of a bribe in the last twelve months of reference (Leo W.J.C. Huberts, Karin Lasthuizen, Carel F.W. Peeters, 2006).

A significant contribution to this data collection activity is offered by a nongovernmental organization, Transparency International (TI), which records the level 
of corruption perceived in all countries of the world. The fundamental tool is the Corruption Perception Index (CPI), which is published annually, starting from 1995, which sorts the countries of the world based on the level of corruption. According to the reports undertaken by TI corruption is understood and perceived by citizens in a broad sense as "the abuse of public offices for private gain". (Transparency International, 2020).

The surveys carried out by Transparency International through the Global Corruption Barometer (GCB) allow, to evaluate the perception of the corruption phenomenon with reference to specific institutions.

The data that emerge from these different detection models have a significant impact on international public opinion as regards the reliability and authoritativeness of institutions and individual economies of the countries (Transparency International, 2013).

State legislators, as a result of international pressure, as well as endogenous needs for renewal of the political and administrative class, have approved over the past decades important measures to combat the corruption phenomenon, not only by intervening on the side of criminal repression, but also operating on the side of administrative prevention. This prevention was realised by introducing new forms of control, rules and standards of behaviour capable of preventing or hindering the implementation of corrupt behaviour by public administrations. This evolution of the anti-corruption policy has also been specifically prompted by several documents adopted by international bodies, with which state authorities have been asked for an integrated approach in the fight against corruption (Transparency International, 2013).

This work aims to examine the most relevant indications that can be drawn from the international legal system, especially from the European one, paying attention not only to the prospect of criminal repression, but also to the administrative prevention activity.

\section{The Legislation provided to fight Corruption in the International Law}

In front of the problems posed by the spread o f corruption practices on an international scale, often carried out by multinational companies, the international community has deemed completely insufficient the path of self-regulation and market sanctions to correct practices or deviant behaviours of economic operators has undertaken a action to promote the harmonization of criminal law provisions both regionally and globally. The preordained initiatives to develop global principles and rules on the responsibility of multinational companies on the fight against corruption have mainly taken the flexible form of the soft law: in particular, codes of conduct, guidelines, corporate social responsibility tools (Berenschot, Imagos Managment and Governance Solutions, 2012). 
The codes of conduct include the Global Compact, an action program launched by the UN Secretary General Kofi Annan in 1999 to encourage transnational companies "to inform their activities and strategies of ten universally accepted principles in the areas of human rights, labour, the environment and the fight against corruption" ( United Nations Global Compact Office , 2007). And of course, the Convention on Combating Bribery of Foreign Public Officials in International Business Transactionsadopted on November 1997 by OSCD countries. As for the guidelines, the Guiding Principles on Business and Human Rights, issued by the UN on 16 June 2011, and the Guidelines for Multinational Companies, drawn up by the OECD in 1976 and updated several times, can be recalled (Conforti, 2018).

Non-binding recommendations have been widely used internationally to combat bribery. The OECD has been very active in issuing several recommendations, such as the Recommendation to further combat the corruption of foreign public officials in economic international transactions of 26 November 2009, or the Recommendation on Strengthening the Integrity in Public Procurement, of 16 October 2008. Furthermore, we can recall the formulation of the Principles for Integrity in Public Procurement in 2009, which highlights the need to take further measures to prevent the risks of corruption during the entire public procurement procedure, starting from the needs assessment phase up to the management of the contract and payment (OECD, 2020; OECD, 2020).

However, the fight against corruption was also conducted with the adoption of pact instruments, attributable to international hard law, based on multilateral agreements and treaties freely adopted by the States. These treaties oblige the States to modify domestic law according to common criminal legislation principles that they have agreed previously before. In the context of international law there are two conventions of a greater importance that must be mentioned, that, marked an important step for the evolution of national criminal systems.

First, we take note of the Organization for Economic Cooperation and Development (OECD) Convention on the fight against bribery of foreign public officials in international business transactions, signed in Paris on 17 December 1997 and entered into force on 15 February 1999. The OECD, while dealing institutionally with economic and social issues, has long since made a commitment against bribery in economic transactions of an international character, insofar as it considers the proliferation of corrupt behaviour an element of distortion of competition and a factor in lowering the civil and political standards of States.

The Convention requires the acceding States to consider a crime for individuals, as well as for legal persons, the fact of bribing foreign officials to obtain undue advantages in international trade. This is an innovative approach, given that at the time of the conclusion of the Agreement in almost all OECD countries the corruption of the foreign public official did not integrate the extremes of crime. As can be seen from the preamble, these provisions should have a deterrent and preventive effect, 
discouraging the spread of corrupt practices by companies in the international market (OECD, 2020).

The relationship between the OECD and the states evolves moreover as a result of the establishment of a special Working Group on Bribery in International Business Transactions (WGB) based on the ratification of the Convention. The Working Groups' was mainly established to support and monitor the implementation of the Convention and, therefore, the coherent translation and application in national laws, in a way to avoid all those forms of implementation that are not faithful to the agreement text (Mongillo, 2012).

The method of continuous monitoring with periodic follow-up was provided, conducted by the WGB and based on a self-assessment system and subsequent mutual evaluation by the contracting States. At the end of the three phases of the monitoring, the WGB issues its recommendations and focuses on the issues to be further monitored. In phase 1, completed in 2001, was verified the abstract compliance of the legislation of the Member States with the commitments entered into force with the ratification of the Convention. In phase 2 that was completed in 2009, the site visits agreed with the foreign country were carried out, during which the concrete application of national laws was examined. Furthermore in the third phase of assessment, which began in 2010 and not yet completed for all contracting countries, focused on the enforcement of the 2009 Convention and Recommendation, on the implementation of the recommendations made to individual countries at the end of phase 2 and, therefore, also on any changes to internal regulations (Mongillo, 2012).

Another convention that bears a significant role is the UN Convention Against Corruption because is the only global legally binding agreement to combat corruption as a transnational phenomenon, known as the UN Convention of Merida on 2003. This Convention provides that the anti-corruption policy must take a twofold direction. On the one hand, it is necessary to activate a series of prevention measures for the public and private sectors, which are specified in Title II, that includes an institutional mechanisms, such as creation of a special anti-corruption body, the adoption of codes of conduct and measures for transparency and accountability (UNITED NATIONS, 2004). With regard to the procurement sector, which is considered particularly overexposed, in article 9 States are required to take the necessary measures to create appropriate public procurement systems that are based on transparency, competition and objective criteria for making decisions and capable of preventing corruption (Webb, 2005).

On the other hand, the Convention, in Title III aims at the improvement of criminal protection by imposing on the States the obligation to give criminal character to a wide variety of infringements related to acts of corruption, if they are not already configured in domestic law as offenses. Great importance is also given to international cooperation in some particular areas, such as mutual legal assistance for the 
collection and transmission of evidence, extradition, freezing, seizure and confiscation of the proceeds from corruption (Webb, 2005).

\section{The Fight Against Corruption in the European Zone}

The legislation drawn up on the initiative of some European supranational institutions, such as the Council of Europe and the European Union conditioned the states' national policies against corruption. In fact, both these institutions, even if they are characterized by different roles and competences, since the mid-nineties, have tried to urge a profound revision of national laws to improve the forms of fighting corruption (Conforti, 2018).

In regional international law, the first goal historically pursued has been to improve the tools of criminal repression. At European level, it was first the Council of Europe that committed itself to the fight against corruption. As it is known, its main method of action to implement a closer union between the Member States is constituted by the activity of coordination and promotion of international agreements or conventions between States Parties (Conforti, 2018). On the side of the fight against corruption on 27 January 1999 the Criminal Law Convention on Corruption was opened for signature in Strasbourg, which constitutes the second major multilateral instrument adopted in this subject matter (Council of Europe, 1999).

The Convention has two fundamental objectives: the first one to coordinate the definition and prosecution of a wide range of corrupt in the sense of the facts, accepting a broad and inclusive notion of "corruption", and improve international cooperation to prosecute these crimes. The Criminal Law Convention on Corruption is also open to the adoption of third States and its implementation is monitored through mutual evaluation cycles between the acceding countries according to the model of peer review (Rau, 2011). In 1999 the Group of States against corruption (GRECO) - was established within the Council of Europe in order to "improve the ability of its members to fight corruption by monitoring, through a dynamic process of mutual evaluation and pressure as an equal, compliance with the commitments undertaken in this field". GRECO was the main forum for the development of specific indications in the European context, given that all the Member States of the European Union are part of it, contributing to defining certain European minimum standards to identify a common legal and institutional framework in the fight against corruption (Rau, 2011).

GRECO, in particularly manages a system of periodic evaluation of the Member States' strategies which culminates in the preparation of reports and recommendations, which constitute the privileged tool for providing information to the member states.

The European Union has also played an increasingly incisive role in the fight against corruption, following the process of "Europeanisation" of criminal law (European Parliament, 2018). This process started with the Maastricht Treaty and culminated with the provisions of the Treaty of Lisbon. During the different phases of the 
European Union's criminal policy, certain acts have been adopted, with a varied legal form, which have been proposed with the objective of harmonization and coordination of national criminal laws in the repression of certain types of crime, such as organized transnational economic crimes (European Parliament, 2018).

In this regard, the Convention on the fight against corruption of public officials of the European Communities and of the Member States of the European Union, approved based on article 3, TEU, in Brussels on 26 May 1997, and entered into force on 28 September 2005. Its fundamental objective is to strengthen judicial cooperation at European level in the fight against corruption, but the Convention introduces for States the obligation to penalize corruption both for domestic officials, including those of other Member States and for the Community officials (Klip, 2016).

The Council Framework Decision 2003/568 / JHA of 22 July 2003 on combating corruption in the private sector, adopted by the Council of the European Union pursuant to Title VI of the Treaty on European Union, as part of the intergovernmental policy for judicial cooperation. The main purpose of the decision is indicated in ensuring that both active and passive corruption in the private sector are considered criminal offenses in all Member States, that even legal persons can be found guilty of such crimes and that the penalties are effective, proportionate and dissuasive (The Council of the European Union, 2003).

Subsequently, the European Union adopted some Community Directives on recycling and self-recycling, in particular the Directive 2005/60 / EC of the European Parliament and of the Council of 26 October 2005, and Directive 2006/70 / EC of the Commission, of August 4, 2006 (Klip, 2016).

\section{European Initiatives for Prevention of Administrative Corruption}

In the context of European legislation, even if the main concern has been addressed to criminal harmonization and therefore to the repression phase, the need has gradually emerged to introduce preventive control mechanisms and tools. In fact, the limits of criminal protection soon became evident to the European institutions, which could not combat adequately the corruption phenomenon, not only because the latter has become widespread and no longer episodic, but also because it was affected by a metamorphosis criminological of the "qualitative" type of corruption. Instead, a strategy based on administrative prevention was approved and, required the use of a multiplicity of legal techniques and involved coordinated action by all administrative subjects who have responsibility for the integrity and correctness of the administrative action (Klip, 2016).

\subsection{The role of the Council of Europe}

Some indications for a strengthening of administrative law institutions were formulated by the Council of Europe. In particular, the Criminal Convention of 1999, stipulated under the guidance of the Council of Europe, although mainly concerning 
criminal aspects, also provided, in art. 20, the creation of a specialized body in terms of administrative prevention, endowed with the independence necessary to carry out its duties (Council of Europe, 1999).

Since 2009, GRECO has drawn up specific reports about the individual member states. Some European member states of GRECO have been subjected to the so-called joint first and second cycle evaluation procedure, which ended with the approval of the Report and its Recommendations during the 43rd assembly, held in Strasbourg from 29 June to 2 July 2009 (Council of Europe, 2009). The report points out that corruption is perceived as a common and widespread phenomenon and affects many sectors of the public administration, that of urban planning, waste disposal, public procurement and health. The recommendations made following this analysis therefore highlighted the lack of a specifically coordinated anti-corruption program, the need to improve specialization and the coordination between the various subjects dealing with the fight against corruption and the importance for the country to implement effective repression, but above all, prevention of corruption measures (Council of Europe, 2009).

With regard to the latter profile, the Recommendations and the Report highlighted the need to provide effective corruption prevention measures, which must cover the different aspects of administrative action, such as the adoption of anti-corruption programs and plans; the development and prescription of coherent ethical standards applicable to all public officials; the development and prescription of clear and binding rules on conflict of interest for all subjects who they perform functions in public administration; and of course the protection for employees who, in good faith, report suspected cases of corruption within the public administration, called the whistle-blowers (Council of Europe, 2009).

\subsection{The role of the European Union}

The European Union, which was originally created for economic and social purposes, has extended its interference on the policies of the Member States in terms of combating corruption, stimulating national authorities to broaden the range of intervention tools with the introduction of administrative prevention measures. Prevention was considered in a 2003 European Commission Communication, which identified ten principles to improve the fight against corruption: the first one being the provision the control upon of a specific position of managers and administrative managers in scope of decision-making processes; also the establishment of specific competent and visible anti-corruption bodies; full accessibility and meritocracy in the management of public assignments; the adoption of quality management tools and control and supervisory standards; the promotion of administrative transparency institutes; the adoption of codes of conduct; the development of protection systems for those who report the offense; the introduction of clear and transparent rules on party financing and control external financial (Commission of the European Communities, 2013). Tackling 
More recently, the EU Commission has intervened with another Communication, in which, after specifying the estimate of the cost of corruption for the EU economy, it envisaged the introduction of a special knowledge instrument, the "EU AntiCorruption Report", which aims to monitor and evaluate the actions taken by the Member States in the fight against corruption and to promote greater political commitment (Klip, 2016). The drafting of this document constitutes the Commission's response to the request by the European Parliament and the European Council, within the framework of the Stockholm Program, to develop tools for the periodic disclosure of Member States' efforts, in order to strengthen the will policy of the States themselves to tackle the issue of corruption. The Report is based on data from different sources: i surveillance and evaluation mechanisms of international organizations (OECD, United Nations, Council of Europe); control activities of European bodies such as the European Anti-Fraud Office (OLAF), Eurojust and Europol; Eurobarometer surveys; the advice of the expert group on corruption set up within to the Commission in 2011 and assisted by a network of researchers present in each Member State; research promoted by civil society; the information provided by the Member States.

The Report is prepared by the Commission and published every two years, starting in 2013, in order to promote correct reflection on the results, weaknesses and commitments of all Member States, identifying existing trends and weaknesses to be addressed and stimulating the exchange of best practices. Any relationship anticorruption, therefore, is intended to examine several cross-cutting issues of particular relevance at European level, as well as more specific issues concerning each Member State (Klip, 2016).

In the EU Corruption Report, presented in February 2014, it is clarified that corruption can take different forms and different levels of severity from country to country and from industry to industry, even if a particular risk is identified in the procurement sector (European Commission, 2014). The Report, after highlighting some data testifying to the relevance of the phenomenon, analyses the changes introduced in the legal systems by recent legislative provisions.

The European Parliament has also taken a stand on the issue of corruption (European Parliament Resolution of 15 September 2011), which adopted a resolution on the European Union's efforts to fight corruption, underlining how the economic and financial recovery of the European area is hampered by corruption. With this resolution, the European Parliament has invited the institutions of the European Union and the Member States to ensure greater transparency of national public systems, by developing codes of conduct or improving those already in force, so as to provide clear rules regarding conflicts of interest, as well as in order to prevent and fight the spread of corruption.

The European Parliament also urged the Council and the Commission to make the network of anti-corruption contact points more efficient, by requesting constant 
information on the network's activities. Overall, these are acts attributable to soft law, which, however, have been able to significantly guide the evolution of national laws. In addition to these general requests, the EU's attention has been paid to some specific sectors, such as that of public contracts, in which the permeability to corrupt practices has been greater. The European Union legislation, based on provisions of the Treaty on the Functioning of the European Union, has introduced many rules to ensure transparency and objectivity in the procurement procedures, precisely to avoid abuses by public officials and collusive practices with businesses. Even in the European 2020 strategy, public procurement plays a fundamental role, as a more efficient use of public resources can allow companies to innovate and participate in international competition.

\section{Conclusion}

The relationship between corruption and democracy is a complex one. However, it is clear from the literature review that the two are closely intertwined. When democracy weakens, there is almost always an increase in corruption due to the loss of institutional checks and balances, fewer independent courts and frequent restrictions on the space for civil society actions and citizens' political rights. Likewise, when corruption is widespread, newly democratic states can hardly consolidate.

Democracy being a system built on effective horizontal accountability need the independency the three constituent powers of the state, the legislative, the executive and the judiciary that must constantly check each-other. Research has concluded that corruption can be fought by strengthening the judiciary by giving them a wide spectrum of effective laws, not just nationally but also regionally and internationally. Young democratic states need the help of international organizations in understanding, drafting and approving of legislation against corruption. In weak democracies the higher the assurance of the independence of the judicial system, the higher will be the provision of impartial application of the law, which leads to the reduction of corruption. In regard to studying the combat upon corruption within the international law we may see that all that has been said so far implies that rules for the fulfilment of international and European law as well as procedures to guarantee their effectiveness, are adopted within States.

The European Union has highlighted the need to provide effective corruption prevention measures, which must cover the different aspects of administrative action, such as the adoption of anti-corruption programs and plans; the development and prescription of coherent ethical standards applicable to all public officials; the development and prescription of clear and binding rules on conflict of interest for all subjects who they perform functions in public administration. The states that require to adhere to these international organizations are obliged to approve the conventions, treaties and agreement in order to harmonize their legislation in accordance with the 
international law that requires to modify domestic law according to common criminal legislation principles that they have agreed previously before.

\section{References}

[1] Berenschot, Imagos Managment and Governance Solutions. (2012). Thematic Evaluation of Rule of Law, Judicial Reform and Fight against Corruption and Organised Crime in the Western Balkans - Lot 3 MAIN REPORT. Brussels: The European Union's IPA Program For Western Balkans.

[2] Bo Rothstein, Aiysha Varraich. (2017). Making Sense of Corruption. Cambridge University Press: Cambridge .

[3] Commission of the European Communities. (2013). Communication from the Commision to the Council (COM 2003/317), the European Parliament and the European Economic and Social Committee on a Comprehensive EU Policy against Corruption. Brussels: Commission of the European Communities.

[4] Conforti, B. (2018). Diritto Internazionale, XI Edizione. Napoli: Editoriale Scientifica.

[5] Council of Europe. (1999). Criminal Law Convention on Corruption . Strasbourg: Council of Europe.

[6] Council of Europe. (2009). Greco Eval I/II Rep (2008) 2E , Joint First and Second Evaluation Round, Evaluation Report on Italy, Adopted by GRECOat its 43rd Plenary Meeting . Strasbourg: Directorate General of Human Rights and Legal Affairs, Council of Europe.

[7] Dahl, M. (2008). How do International Organizations Scrutinize Transforming States? The Case of Transparency International and the Baltic States. In P. M. Luid De Sousa, Governments, NGOs and AntiCorruption. The new integrity warriors (pp. 223-256). London: Abingdon, Routledge.

[8] David Collier, Steven Levitsky. (1997). Democracy with Adjectives: Conceptual Innovation in Comparative Research. World politics, Volumme 49, Issue 3, 430-451.

[9] European Commission. (2014). Report from the Commission to the Council and the European Parliament COM (2014)38 final. Brussels: European Commission.

[10] European Parliament. (2018). Criminal procedural laws across the European Union - A comparative analysis of selected main differences and the impact they have over the development of EU legislation. Brussels: European Parliament, Directorate General for Internal Policies.

[11] Hanna Back, Axel Hadenius. (2008). Democracy and State Capacity: Exploring a J-Shaped Relationship. Governance: an International Journal of Policy, Administration and Institutions, 1-24. 
[12] Klip, A. (2016). European Criminal Law- Series "Ius Communitatis". Berlin: Intersentia.

[13] Leo W.J.C. Huberts, Karin Lasthuizen, Carel F.W. Peeters. (2006). Measuring Corruption: Exploring the Iceberg. In A. S. Charles Sampford, Measuring Corruption (pp. 265-293). Farnham: Ashgate Publishing.

[14] Merkel, W. (2004). Embedded and defective democracies. Democratization: Consolidated \& Defective Democracy? Problems of Regime Change, Volume 11, Issue 5, 33-58.

[15] Mo, P. H. (2001). Corruption and Economic Growth. Journal of Comparative Economics, Volume 29, Issue 1, 66-79.

[16] Mongillo, V. (2012). La Corruzione tra Sfera Interna e Dimensione Internazionale. Milano: il Mullino.

[17] Morlino, L. (2004). What is a 'good' democracy? Democratization, Volume 11 , Issue $5,10-32$.

[18] Munck, G. L. (2016). What is democracy? A reconceptualization of the quality of democracy. Democratization, Volume 23, Issue 1, 1-26.

[19] OECD. (2020, March 1). Convention on Combatin Bribery of Foreign Public Official in International Business Transactions and Related Documents. Retrieved from Organisation for Economic Co-operation and Development, Bribery in International Business: http://www.oecd.org/daf/anti-bribery/ConvCombatBribery_ENG.pdf

[20] Pablo M. Pinto, Boliang Zhu. (2016). Fortune or Evil? The Effect of Inward Foreign Direct Investment on Corruption. International Studies Quaterly, Volume 60, Issue 4, 693-705.

[21] Philippe C. Schmitter, Terry Lynn Karl. (1991). What Democracy Is... and Is Not. Journal of Democracy, Volume 2, Number 3, 75-88.

[22] Rau, W. (2011). he Group of States against Corruption (GRECO) Operation and Results from its Current Third Evaluation Round. In D. H. Lucas Achathaler, Korruptionsbekämpfung als globale Herausforderung (pp. 19-36). Berlin: Springer VS.

[23] Robinson, M. (2007). Corruption and development: An introduction. The American Political Science Review, 1-14.

[24] Selen A. Ercan, Jean-Paul Gagnon . (2014). The Crisis of Democracy: Which Crisis? Which Democracy? Democratic Theory, Volume 1, Issue 2, 1-10.

[25] Šumah, Š. (2018). Corruption, Causes and Consequences. In V. B. (Ed), Trade and Global Market (pp. 1-14). Slovenia: Intechopen.

[26] Susan Rose-Ackerman, Bonnie J. Palifka. (2016). Corruption and Government: Causes, Consequences, and Reform. Cambridge: Cambridge University Press.

[27] Teachout, Z. (2018). The Problem of Monopolies \& Corporate Public Corruption. Dædalus, the Journal of the American Academy of Arts \& Sciences, Summer 2018, 111-126. 
[28] The Council of the European Union. (2003). Council Framework Decision 2003/568/JHA on combating corruption in the private sector. Brussels: The Council of the European Union.

[29] The Financial Action Task Force (FATF) . (2020). FATF Report to the G20 Finance Ministers and Central Bank Governors on So-called Stablecoins. Paris: The Financial Action Task Force (FATF) .

[30] Transparency International. (2013). Global Corruption Barometer 2013. Berlin: Transparency International.

[31] Transparency International. (2020). Corruption Perceptions Incex 2019. Berlin: Transparency International.

[32] UNITED NATIONS. (2004). UNITED NATIONS Convention Against Corruption. New York: UNITED NATIONS.

[33] United Nations Office on Drugs and Crime (UNODC). (2018). Manual on Corruption Surveys: Methodological guidelines on the measurement of bribery and other forms of corruption through sample surveys. Vienna: United Nations Development Programme .

[34] (United Nations Global Compact Office . (2007). After the Signature: A guide to Engagement in the United Nations Global Compact. New York: United Nations Global Compact Office .

[35] Webb, P. (2005). The United Nations Convention Against Corruption: Global Achievement or Missed Opportunity? Oxford Journal of International Economic Law, Volume 8, Issue 1, 191-229.

[36] Wells, J. (2014). Corruption and Collusion in Construction: a View from the Industry. In A. W. Tina Soreide, Corruption, Grabbing and Development: Real World Challenges (pp. 23-35). Northhampton: Edward Elgar. 